\title{
Front Matter: Volume 12050
}

, "Front Matter: Volume 12050," Proc. SPIE 12050, International Conference on Smart Transportation and City Engineering 2021, 1205001 (10 November 2021); doi: 10.1117/12.2623682

SPIE Event: 2021 International Conference on Smart Transportation and City Engineering, 2021, Chongqing, China 


\title{
PROCEEDINGS OF SPIE
}

\section{International Conference on Smart Transportation and City Engineering 2021}

\author{
Zhengliang Li \\ Fengjie Cen \\ Editors
}

$26-28$ October 2021

Chongqing, China

\section{Organized by}

China Merchants Chongqing Communications Technology Research \& Design Institute Co., Ltd. Chongqing University (China)

Chongqing Jiaotong University (China)

Sponsored by

AEIC Academic Exchange Information Centre (China)

Published by

SPIE

Volume 12050

Part One of Two Parts 
The papers in this volume were part of the technical conference cited on the cover and title page. Papers were selected and subject to review by the editors and conference program committee. Some conference presentations may not be available for publication. Additional papers and presentation recordings may be available online in the SPIE Digital Library at SPIEDigitalLibrary.org.

The papers reflect the work and thoughts of the authors and are published herein as submitted. The publisher is not responsible for the validity of the information or for any outcomes resulting from reliance thereon.

Please use the following format to cite material from these proceedings:

Author(s), "Title of Paper," in International Conference on Smart Transportation and City Engineering 2021 , edited by Zhengliang Li, Fengjie Cen, Proc. of SPIE 12050, Seven-digit Article CID Number (DD/MM/YYYY); (DOI URL).

ISSN: 0277-786X

ISSN: 1996-756X (electronic)

ISBN: 9781510649750

ISBN: 9781510649767 (electronic)

Published by

SPIE

P.O. Box 10, Bellingham, Washington 98227-0010 USA

Telephone +1 3606763290 (Pacific Time)

SPIE.org

Copyright (C) 2021 Society of Photo-Optical Instrumentation Engineers (SPIE).

Copying of material in this book for internal or personal use, or for the internal or personal use of specific clients, beyond the fair use provisions granted by the U.S. Copyright Law is authorized by SPIE subject to payment of fees. To obtain permission to use and share articles in this volume, visit Copyright Clearance Center at copyright.com. Other copying for republication, resale, advertising or promotion, or any form of systematic or multiple reproduction of any material in this book is prohibited except with permission in writing from the publisher.

Printed in the United States of America by Curran Associates, Inc., under license from SPIE.

Publication of record for individual papers is online in the SPIE Digital Library.

\section{SPIE. DIGITAL}

Paper Numbering: A unique citation identifier (CID) number is assigned to each article in the Proceedings of SPIE at the time of publication. Utilization of CIDs allows articles to be fully citable as soon as they are published online, and connects the same identifier to all online and print versions of the publication. SPIE uses a seven-digit CID article numbering system structured as follows:

- The first five digits correspond to the SPIE volume number.

- The last two digits indicate publication order within the volume using a Base 36 numbering system employing both numerals and letters. These two-number sets start with 00, 01, 02, 03, 04, 05, 06, 07, 08, 09, 0A, OB ... 0Z, followed by 10-1Z, 20-2Z, etc. The CID Number appears on each page of the manuscript. 


\section{Contents}

\section{INTELLIGENT SIGNAL AND INFORMATION COMMUNICATION TECHNOLOGY}

1205002 A conceptual framework of underground pipeline relocation management through building information modeling and geographic information system integration [12050-62]

1205003 Investigation of lane-changing decision-making models for autonomous vehicles [12050-87]

$1205004 \quad$ Robust vehicle classification using sound signals and attention module [12050-14]

1205005 Optimization of emergency material distribution path for public emergencies [12050-70]

1205006 Optimization of drone and truck emergency delivery using artificial bee colony-Clarke-Wright algorithm [12050-100]

1205007 Analysis on research hotspots and trends of cooperative vehicle infrastructure system based on mapping knowledge domains [12050-133]

1205008 Research on drainage capacity of road plastic blind trench based on numerical simulation [12050-40]

1205009 Automatic information retrieval with semantic analysis for green building evaluation [12050-24]

12050 OA Research on influencing factors of follow-up distance in curves based on driving simulator [12050-89]

12050 OB Automatic roadway stack calibration based on geographic information system secondary development technique [12050-69]

12050 OC Building information modelling implementation in prefabricated building research field and barriers analysis [12050-16]

12050 OD The life convenience analysis for Shenzhen urban area based on POI data [12050-66]

12050 OE Civil engineering process file information management system [12050-61]

12050 OF Study on the influence of tire parameters on vehicle driving performance [12050-157]

12050 OG Study on optimal evaluation of route design scheme in mountain highway reconstruction and expansion [12050-58]

$12050 \mathrm{OH} \quad$ Research on vehicle speed estimation method based on microphone array [12050-57] 
12050 Ol Finite element analysis of the construction of the Tower of Pisa [12050-163]

12050 oJ Civil engineering professional certification management information system [12050-51]

12050 OK Multi-detector layout method of transit signal priority control comprehensively considering the priority strategies and speed fluctuations [12050-31]

12050 OL Research on screening methods of autonomous driving dangerous test cases based on Carmaker [12050-73]

12050 0M A report of defective automobile recalls in China from 2004 to 2020 [12050-241]

12050 ON Evaluation methods of automatic driving behavior based on the actual road test [12050-127]

1205000 Research on three-dimensional visualization modeling of roadbed slope structure, presentation of vector information and development of display module [12050-119]

12050 OP The internet of things integrated management system of civil engineering laboratory [12050-59]

$120500 Q \quad$ Research on construction of three-dimensional visual model of roadbed slope and its lightweight display [12050-88]

12050 OR Data cleaning system and method based on IC card data characteristics [12050-169]

12050 OS Deflection prediction analysis of corrugated steel web composite box-girder bridge based on MEC-BP neural network [12050-1]

12050 OT Optimal path decision algorithm based on data fusion [12050-65]

$12050 \mathrm{OU} \quad$ Study on stability calculation of overloaded abandoned dreg site based on particle flow theory [12050-118]

12050 OV Numerical analysis of vibration isolation trench under dynamic compaction [12050-128]

12050 OW Research on current status of autonomous emergency braking vulnerable road users test and evaluation in new car assessment programme [12050-120]

12050 0X Research on deceleration lane length for B-type trumpet interchange [12050-152]

12050 OY Dynamic management system of large-scale water conservancy project construction based on ArcGIS [12050-234]

$120500 Z$ Research on risk prediction methods of informationized water conservancy projects [12050-146]

1205010 Operation management architecture of power communication backbone transmission network based on big data [12050-186]

1205011 Dynamic scheduling strategy of shared vehicles based on time series [12050-167] 
1205012 Experimental study on the dust suppression effect of water cannon mud in drilling and blasting tunnel [12050-176]

1205013 A study on the development of the Busan coastal line office environment with vertical landscapes [12050-209]

1205014 Comparison and selection of feeder transit between flex-route transit and fixed-route transit [12050-182]

1205015 Research on the concept and application of highway cost control and management in the whole process [12050-231]

1205016 Application of building information modeling in the project management life cycle [12050-185]

1205017 Development and depth application of building information modeling 5D technology in construction industry [12050-162]

1205018 Research on development of a handy building information model application tool for decoration project [12050-188]

\section{SMART TRANSPORTATION AND TRANSPORTATION LOGISTICS PLANNING}

1205019 Research on coordination and optimization of rail transit and feeder bus operation in suburban section [12050-129]

120501 A Research on highway accident prediction based on interactive highway safety design model [12050-39]

12050 1B Study of expressways with heavy traffic flow during occupying-road construction [12050-125]

$120501 C \quad$ Speed limit model of expressway in rain and fog [12050-64]

12050 1D Smart planning for waterway transportation of imported iron ore in the Yangtze River Delta [12050-135]

$12050 \mathrm{lE}$ The integrated design of integrated transport hub: taking Xizhimen as example [12050-10]

$12050 \mathrm{lF} \quad$ Analysis of influencing factors of mountain secondary highway accidents based on logistic regression model [12050-45]

$120501 G \quad$ Comprehensive transportation planning research under the background of a strong transportation country: taking Ziyuan County as an example [12050-107]

$12050 \mathrm{lH}$ Multi-criteria and multi-class traffic user equilibrium model under uncertainties [12050-197]

$1205011 \quad$ Reliability calculation of connectivity considering travel cost [12050-99]

$120501 \mathrm{~J}$ Reinforcement learning in intelligent transportation systems: recent developments [12050-34] 
12050 1K Shenzhen Expressway Intelligent Management and Maintenance System and its application [12050-20]

$120501 \mathrm{~L} \quad$ Vehicle-to-vehicle blind spot monitoring system test method [12050-90]

$120501 \mathrm{R} \quad$ Resident travel path planning based on risk assessment of epidemic-related areas [12050-27]

$120501 \mathrm{~N} \quad$ Traffic safety evaluation based on unascertained measure model [12050-28]

1205010 Research on the basis of the setting of the dedicated left-turn lane at the two-phase intersection [12050-78]

$120501 \mathrm{P} \quad$ Application of interpolation method in data processing of dangerous cargo transportation in the Yangtze River [12050-55]

$120501 Q \quad$ The analysis about the setting methods of a smart traffic marking [12050-9]

12050 IR Construction of seismic disaster scenario for road traffic network in mountainous city [12050-5]

12050 is Research on the optimization of urban logistics terminal distribution route based on mileagesaving algorithm [12050-4]

$120501 \mathrm{~T} \quad$ Seepage analysis of highway subgrade in Guizhou mountainous area based on numerical simulation [12050-35]

$120501 \mathrm{R} \quad$ Research on layout optimization in sea-rail transportation [12050-46]

$120501 \mathrm{~V} \quad$ Analysis of the influencing factors of traffic accidents based on the logistics method [12050-50]

12050 IW Performance evaluation of bus transfer nodes based on Advanced Public Transportation System data [12050-93]

12050 1X Reliability analysis of dynamic travel time of public transport based on Advanced Public Transportation System data [12050-95]

12050 1Y Study on the strategic planning of combination port in China [12050-23]

$1205012 \quad$ Study on traffic organization design of expressways with heavy traffic flow during occupyingroad construction [12050-74]

$1205020 \quad$ Research on improvement of urban rail transit energy consumption model [12050-97]

$1205021 \quad$ Traffic congestion recognition based on information entropy [12050-86]

1205022 Research on new material scale model technology of rail transit vehicles based on similarity theory [12050-243]

1205023 Optimization method for urban intersection and empirical research from the perspective of safety [12050-108] 
$1205024 \quad$ Facilities design of small clusters of pedestrians release at section crosswalk [12050-84]

1205025 Research on the construction of highway traffic measurement standardization system [12050-3]

1205026 Research on the interchange hub system of combined public transport [12050-103]

1205027 Research on the spatial pattern of traffic accessibility and economic connection in Guanzhong urban agglomeration [12050-156]

1205028 Research on the status quo of risk control in land and island transportation in China [12050-81]

1205029 Research on application of automatic driving main-routes logistics in China [12050-92]

12050 2A A noise-immune extreme learning machine for short-term traffic flow forecasting [12050-134]

12050 2B Information security risk assessment methods for the transportation industry [12050-112]

$120502 \mathrm{C} \quad$ Research on autonomous emergency braking two-wheeler test and evaluation method combined with traffic accident characteristics [12050-122]

12050 2D Research on the setting method of the left-turn lane of the bus [12050-104]

$120502 \mathrm{E} \quad$ Research on path design and collision avoidance strategy of automated guided vehicle transportation system [12050-192]

$120502 \mathrm{~F} \quad$ Overview of highway ecological route selection [12050-170]

$120502 \mathrm{G} \quad$ Prediction method of urban traffic carbon emission reduction rate based on grey relational analysis [12050-225]

\section{SMART GRID AND ENERGY-SAVING SAFETY SYSTEMS}

$120502 \mathrm{H} \quad$ City electricity forecast based on the GM $(1,1)$ model of metabolism $[12050-13]$

$1205021 \quad$ Study on the application of intelligent security technology in ports [12050-85]

12050 2J Research on location selection of electric vehicle charging station based on improved immune algorithm [12050-37]

12050 2K Cyber security risk analysis and evaluation for intelligent vehicle gateway [12050-8]

$120502 \mathrm{~L} \quad$ Simulation analysis and optimization of thermal management for a certain type of locomotive battery charger [12050-94] 
$120502 M$

$120502 N$

1205020

$120502 P$

$120502 Q$

$120502 R$

$120502 S$

$120502 T$

$120502 \mathrm{U}$

$120502 V$

$120502 W$

$120502 X$

$120502 Y$

$120502 Z$

1205030

1205031

\section{Part Two}

1205032 Technical and economic analysis of high water collecting tower and conventional natural

Research on comprehensive evaluation method of green ecological road based on extension cloud model [12050-67]

Research on urban carbon balance based on system dynamics: a case study of Tianjin city [12050-144]

Overall architecture design for smart water network construction [12050-183]

Research and practice on index system of county multi-layer water utilization control [12050-236]

Application of the high-density resistivity method to detect the hidden trouble in the mine sewage dam [12050-177]

Comparative study on energy consumption of AAC green prefabricated dwellings based on BIM technology [12050-159]

Efficiency improvement of intelligent water resources and hydraulic transient detection [12050-238]

Collision-proof safety rating model of wave beam guardrail based on entropy weight technique for order preference by similarity to an ideal solution [12050-18]

Analysis of water resources supply and demand structure in Beijing-Tianjin-Hebei region from the perspective of water footprint [12050-179]

Key technology research on water networking based intelligent water construction [12050-239]

The performance of distributed rooftop photovoltaic power generation system: a case of Anhui Province, China [12050-200]

Research on operation and maintenance plafform of high voltage transmission line slope [12050-145]

Health monitoring method of transmission tower based on association rule algorithm [12050-187]

Experimental case analysis of solar air collector and heating system in rural areas of North China [12050-147] 
1205033 Research on new energy cooperation based on system dynamics model [12050-216]

$1205034 \quad$ Evaluation of distribution network dispatching management level based on the construction demand of smart city distribution network [12050-150]

1205035 A study on water quality prediction by a hybrid dual channel CNN-LSTM model with attention mechanism [12050-149]

1205036 Study on energy-saving thermal environment of residential envelope reconstruction based on ECOTECT [12050-158]

$1205037 \quad$ Research on building energy consumption modeling and spatial analysis method in China [12050-227]

1205038 Prediction of subjective charging behavior of electric vehicles based on improved deep residual network [12050-21]

1205039 Characteristics of sandbody and sedimentary facies of Yan 8 reservoir of Yan'an formation in X Area [12050-232]

12050 3A Analysis on the multi-year change of water quality and pollution causes in Luoyuan Bay [12050-218]

12050 3B Research and accounting of VOCs emissions from key industrial sources in a city [12050-211]

\section{SMART CITY AND SMART CONSTRUCTION INSPECTION}

$120503 \mathrm{C} \quad$ Study on the effect of reinforcing method of inclined jet grouting pile to control the uneven settlement of soft soil subgrade [12050-244]

12050 3D Consideration of parking allocation in urban commercial center based on the carrying capacity of road network [12050-102]

12050 3E Effect of chord compression on the ultimate strength of ring-stiffened tube-gusset KT-type and X-type joints [12050-98]

12050 3F Quality index and measurement method of public space in existing residential district [12050-175]

$120503 \mathrm{G} \quad$ Research on the support system of strengthening and rebuilding project in a university [12050-114]

$120503 \mathrm{H} \quad$ Response analysis of different brace forms erected in the foundation pit excavation of metro station to deformation values [12050-121]

$1205031 \quad$ Numerical study of the effects of artificial island on water environment: a case study of Ocean Flower Island in Hainan, China [12050-56]

12050 3J Research on the application of intelligent building technology based on DMBP in Western China [12050-2] 
12050 3K Design of combined pipe support with large span steel structure [12050-115]

$120503 \mathrm{~L} \quad$ Analysis of influencing factors of construction characteristics for calcium carbide residue stabilized soil [12050-111]

$120503 \mathrm{M} \quad$ Correlation between intelligent compaction index and compaction degree of asphalt pavement [12050-72]

$120503 \mathrm{~N} \quad$ Analysis of urban residential spaced design under the guidance of epidemic prevention [12050-219]

1205030 Research on the improvement of urban waterfront area design: focused on smart city construction [12050-191]

12050 3P Research on the smart tourism based on AR visualization design application [12050-213]

$120503 Q \quad$ Discussion on the evolution of digital city management to smart city management in prefectural cities [12050-165]

$120503 R \quad$ Analysis of urban community disaster characteristics and study on emergency management mechanism [12050-190]

1205035 A study on the path to realize the conservation and utilization of historical buildings and the synergistic development of cities [12050-155]

12050 3T Design of remote test system for structural reinforcement of high-rise buildings under strong earthquake environment [12050-230]

$120503 \mathrm{U} \quad$ Study on preparation and properties of waterborne epoxy-emulsified asphalt material [12050-7]

$120503 V \quad$ A design of railway intelligent obstacle detection system [12050-15]

12050 3W Seismic performance analysis of precast segmental bridge columns with self-centering energy dissipation device [12050-26]

$120503 X \quad$ Characteristic analysis and behavior prediction method of converging behavior in urban expressway weaving section [12050-77]

$120503 Y \quad$ Calculating method of arch rib installation alignment of large span cable hoisting arch bridge [12050-131]

$120503 Z$ Study on the sliding resistance and mechanical properties of two-component epoxy resin antisliding thin layer [12050-109]

$1205040 \quad$ Influence of hopper inclination at bottom of silo on separation of mixture [12050-83]

$1205041 \quad$ Study on the application of modified bitumen technology in the maintenance engineering of secondary highway [12050-138]

$1205042 \quad$ Analysis of rail corrugation characteristics based on PSD [12050-82] 
1205043 Study on mechanical characteristics of large section tunnel construction in soft surrounding rock [12050-17]

$1205044 \quad$ Geometric reconstruction of buildings by using dimension features [12050-141]

1205045 Research on longitudinal deformation characteristics of shield tunnel segment under water level change [12050-60]

1205046 Stability analysis and landslide forecast of XiaoJiang gravel soil slope in Baihetan area [12050-164]

$1205047 \quad$ Vibration frequency of modified wave beam guardrail based on collision simulation and vibration acceleration analysis [12050-41]

1205048 Research on impact resistance of pier protection device [12050-194]

1205049 Research on elastic recoverable protection structure [12050-178]

$120504 \mathrm{~A}$ Analysis of key parameters in the bearing capacity evaluation of continuous rigid frame bridges [12050-44]

12050 4B Road capacity calibration of medium and small cities based on radial basis function neural network [12050-71]

12050 4C Effect of geo-synthetics location on the uneven settlement of roadbed [12050-80]

$120504 \mathrm{D}$ Comparative experimental study of the influence of steel strand tensioning process on the strand force uniformity in steel strand stay cables [12050-161]

$120504 \mathrm{E} \quad$ Analysis of factors affecting stress and displacement of corrugated steel pipe culvert with large span and high depth [12050-6]

$120504 \mathrm{~F}$ Smart city development: research on major infrastructure policy and project appraisal in the UK [12050-19]

$120504 \mathrm{G}$ Research and application of post-doped fire-retardant epoxy asphalt tunnel pavement [12050-139]

$120504 \mathrm{H} \quad$ Research on deformation characteristics of frost heaving and thaw collapse of the high-speed railway subgrade in seasonal frozen areas [12050-221]

120504 Study on deformation coordinated control structure and construction technology of road section containing structure [12050-228]

$120504 \mathrm{~J} \quad$ Study on structural design and construction technology of road widening in retaining wall section [12050-229]

12050 4K Experimental study on single line wetting compression of coarse-grained soil [12050-222]

$120504 \mathrm{~L}$ Research on application of reinforcement method for soft ground along beach [12050-237] 
$120504 \mathrm{M} \quad$ Numerical simulation of flood control and drainage and water environment improvement project in Shangyu [12050-193]

$120504 \mathrm{~N} \quad$ Calculation and analysis of diversion tunnel structure based on ANSYS [12050-233]

1205040 Structural design of number one tunnel on a new line [12050-198]

12050 4P Construction safety assessment of high-piled wharf based on BIM technology [12050-174]

$120504 Q \quad$ Test research of dynamic behavior of medium and low speed maglev train-rail-girder system [12050-143]

$120504 R \quad$ Internal force calculation of half through arch bridge based on elastic foundation beam algorithm [12050-201]

$1205045 \quad$ Internal force calculation of long span suspension bridge under vertical load based on elastic foundation beam algorithm II [12050-217]

$120504 T \quad$ LVS guidance based output-feedback path-following control for underactuated surface vessels [12050-153]

$120504 \mathrm{U} \quad$ Study on the application of aerobic composting technology of organic solid waste in urban communities [12050-224]

$120504 \mathrm{~V} \quad$ Improving emergency response to natural disasters: considering the potential risks of an investment decision method of urban critical infrastructure [12050-204]

12050 4W Visualized analysis in China's architectural industrialization research field based on Citespace [12050-207]

$120504 X \quad$ Study of wind loads on curved free-standing canopy roofs [12050-205]

$120504 Y \quad$ Study of lateral-force resistance performance of integration of shelf-structure and mainstructure shelf structure system [12050-189]

\section{MONITORING REMOTE SENSING TECHNOLOGY AND SENSING IMAGE RECOGNITION}

$120504 Z \quad$ Research on the standard status and test methods of driver attention monitoring system [12050-148]

1205050 Research on the accessibility of intelligent mass transit system based on Arc GIS [12050-242]

$1205051 \quad$ Research on internal trumpet interchange [12050-11]

1205052 Out-of-sequence measurement processing method based on multi-sensor fusion filtering [12050-124]

1205053 Critical path identification method of intersection group considering path relevance [12050-30] 
1205054 Dynamic risk assessment and early warning technology for oil terminal based on catastrophe theory [12050-79]

1205055 Aircraft image recognition in airport flight area based on deep transfer learning [12050-22]

1205056 Creation of high definition map for autonomous driving within specific scene [12050-47]

1205057 Interferometric synthetic aperture radar data selection based on topographic factors [12050-68]

1205058 Stability analysis and disease treatment of Nanmu Bridge slope clone [12050-49]

1205059 Analysis of heart rate variability of drivers on various roadway conditions [12050-117]

$120505 \mathrm{~A} \quad$ An aircraft heading release strategy based on speed obstacle method [12050-110]

12050 5B Classification of terresrial laser scanning data based on multi-dimensional geometry features [12050-36]

12050 5C Analysis of braking effect of advanced driver assistance system in the scenario of cut-in [12050-168]

$120505 \mathrm{D}$ Research on monitoring system of subgrade slope dangerous rock based on Harris corner detection algorithm [12050-166]

$120505 \mathrm{E} \quad$ Research on automatic identification methods for apparent damage of concrete structure bridge based on YOLOv4 [12050-48]

$120505 F \quad$ Study on stability analysis and treatment measures of dangerous rock [12050-53]

1205056 Research on image algorithm of road slope dangerous rock based on fusion template [12050-172]

$120505 \mathrm{H} \quad$ Application and development of weather radar predicting windshear function in civil aviation [12050-63]

$1205051 \quad$ Application of BIM, VR, and GIS technologies in water environmental in-situ monitoring and management [12050-25]

12050 5J Application of improved grey system in tunnel monitoring [12050-101]

$120505 \mathrm{~K}$ Research on subjective evaluation method of navigation guidance level-2 automatic driving system [12050-96]

$120505 \mathrm{~L} \quad$ Micromechanical simulation of ring tension crack test of asphalt concrete based on computer tomography recognition [12050-54]

$120505 \mathrm{M} \quad$ Application of MEMS sensors in abnormal deformation monitoring of metro tunnel structure [12050-75] 
$120505 \mathrm{~N} \quad$ Research status and prospect of tunnel blasting excavation method based on MWD technology [12050-208]

1205050 Research on Intelligent Safety Monitoring and Control System for Work-at-Height (ISMCS-WH) [12050-160]

12050 5P Comparison and prospect of deformation monitoring technology in engineering construction [12050-240]

$120505 Q \quad$ Current status and prospects of research on rockburst prediction in deep tunnels [12050-199]

12050 5R Investigation of sampling frequency impacts on turbulence intensity analysis [12050-203]

$120505 S \quad$ Remote detection method of concrete bridge surface cracks based on digital image [12050-235]

$120505 \mathrm{~T} \quad$ Stability analysis by finite element method and treatment measures of slide slope in open-pit coal mine [12050-223]

$120505 \mathrm{U} \quad$ Research on real-time calculation of geological disaster monitoring data based on GNSS technology [12050-184]

12050 5V Deformation and digitization analysis of after-treatment methods in soft soil [12050-154]

12050 5W Stratigraphic and structural characteristics of Yan 9 oil-bearing group in D area of Ordos Basin [12050-215]

$120505 X \quad$ Geological hazard risk assessment of oil and gas gathering and transportation pipeline based on ARCGIS [12050-173]

$120505 Y \quad$ Spatial distribution characteristics of nutrients in Dianchi lakeside [12050-226]

$120505 Z$ Remote sensing analysis of urban expansion in Guanzhong-Tianshui economic zone [12050-206]

1205060 Assessing the accessibility of urban green spaces in the central Wuhan based on geographic information system and remote sensing [12050-212]

$1205061 \quad$ The accessibility analysis of urban green spaces based on VHR images: a case study of Chongqing [12050-210]

1205062 The spatio-temporal evolution law of beach morphological features: taking Qujiang River in Longyou County as an example [12050-140]

$1205063 \quad$ Comprehensive geophysical methods and core digitization: a case study of a polymetallic mining area in Northeast China [12050-220] 